DOI: 10.19195/0137-1150.167.6

\author{
ALINA ORŁOWSKA
}

Uniwersytet Marii Curie-Skłodowskiej w Lublinie, Polska

\title{
Śmierć to nie kres istnienia... Oblicza śmierci w poezji masońskiej Michaiła Chieraskowa
}

Upadek autorytetu Kościoła prawosławnego, podporządkowanego w wyniku reform Piotra I władzy świeckiej, niepokoje społeczne (powstanie Pugaczowa i następująca po nim fala represji) i pogłębiający się kryzys wiary implikowały w środowisku rosyjskich elit społecznych w ostatnich dziesięcioleciach XVIII wieku poszukiwanie nowych, doskonalszych form życia duchowego oraz zainteresowanie doktryną masońską, zapowiadającą odrodzenie pełnego występku i sprzeczności świata, kładącą nacisk na poznanie Boga, natury i samego siebie poprzez moralne doskonalenie się.

Idea wolnomularska, zorientowana na kształtowanie szlachetniejszej i rozumniejszej jednostki, skoncentrowana na tym, co łączy ludzi w ich dążeniu do osiągnięcia harmonii ze światem, była formą zaspokojenia potrzeb metafizycznych człowieka. Ezoteryczna dogmatyka i obrzędowość masońska stanowiły wielopoziomowy system symboli i alegorii, antycypujący właściwy sposób rozumienia i przedstawiania świata.

Bóg, Stwórca, Wielki Architekt - twierdzili wolnomularze - niezależnie od tego, jakim imieniem jest nazywany, jest jeden. Każda cząstka stworzonego przez Niego świata jest Jego emanacją — „wszystko jest jednym, jedno jest wszystkim"1. Człowiek, podobnie jak świat, pogrążył się jednak w chaosie. Aby ponownie osiągnąć harmonię z odwiecznym porządkiem dzieła bożego, musi się odrodzić. Jego obowiązkiem jest więc wewnętrzne doskonalenie się, pogłębiona refleksja nad sensem istnienia, przemiana „człowieka cielesnego” w „człowieka duchowego", to jest przeistoczenie „dzikiego, nieociosanego kamienia” w „kamień kubiczny, duchowy" ". Dla masona było to równoznaczne z symboliczną

${ }^{1}$ Charakterystyka filozoficznej koncepcji; słowa przypisywane przez wolnomularzy Hermesowi Trismegistosowi. Zob. T. Cegielski, Sekrety masonów, Warszawa 1992, s. 25.

2 Т. О. Соколовская, Обрядность вольных каменщиков, [w:] Масонство в его прошлом и настоящем, red. С. П. Мельгунов, Н. П. Сидоров, t. 2, Москва 1915, s. 98. 
śmiercią i zmartwychwstaniem, ponownymi narodzinami w nowej już formie. Śmierć, wszechobecna w naukach i obrzędach masońskich, dla braci nie była więc kresem życia, lecz początkiem doskonalszej formy istnienia — Złotego Wieku. Odrodzony człowiek, uwolniwszy się od marności świata i pokonawszy śmierć, doświadczał wówczas radości obcowania ze Stwórcą. Poznania niepoznawalnego, które możliwe było tylko dzięki objawieniu, mogli jednak dostąpić tylko wybrani.

Przekonanie o perspektywie osiągnięcia harmonii z idealnym boskim porządkiem splata się w obrzędach, traktatach i literaturze masonów z refleksją nad ułomnością ludzkiej natury, nicością i udrękami ziemskiej egzystencji. Świadomość nieuchronności śmierci ciągle towarzyszyła wtajemniczonym, była integralną częścią rytuałów i obrzędów lożowych. Obrządek inicjacyjny wolnomularza, elementy wystroju loży oraz symbole masońskie uświadamiały braciom ulotność życia, obecność granicy pomiędzy istnieniem cielesnym a duchowym ${ }^{3}$. Zaangażowanie w pracę loży nakładało na nich na każdym etapie ich rozwoju duchowego obowiązek refleksji nad swoim miejscem w świecie, sensem istnienia, nieustannego dążenia do doskonałości, do zbliżania się do Boga — mądrego stwórcy świata.

Iwan Łopuchin $^{4}$ w traktacie Нравоучительный катехизис истинных франкмасонов (Katechizm moralny prawdziwych frankmasonów, 1780) nauczał współbraci, że przed masonem, który pokonał grzeszną naturę, otwierają się bramy królestwa bożego:

Когда не останется ни единой воли, которая бы не совершенно покорилась Богу; когда золотой век, который Бог хочет прежде внутреннее восстановить в малом своем избранном Народе, распространится везде и явится внешне; когда Царство самой Натуры освободится от проклятия и возвратится в Средоточие Солнца; тленное облечется в нетление, мертвенное в бессмертие; смерть испразднится; и будет Бог всяческая во всех 5 .

Z kolei Siemion Hamalija ${ }^{6}$ w mowie wygłoszonej 16 grudnia 1782 roku w loży Diewkalion, rozważając nieuniknioność śmierci, apelował do serc i umysłów braci:

${ }^{3}$ Ibidem, s. $80-118$.

${ }^{4}$ Iwan Łopuchin (1756-1816) — wybitny rosyjski mason-różokrzyżowiec. Zob. Русская философия второй половины ХVIII века. Хрестоматия, red. Б. В. Емельянов, Свердловск 1990, s. 264-266; Н. К. Пиксанов, И. В. Лопухин, [w:] Масонство в его прошлом и настоящем, red. С. П. Мельгунов, Н. П. Сидорова, t. 1, s. 227-255; А. Незеленов, Литературные е направления в Екатеринскую эпоху, Санкт-Петербург 1898, s. 171-173.

${ }^{5}$ И. В. Лопухин, Нравоучительный катехизис истинных франкмасонов для употребления ищуших премудрости, [w:] idem, Масонские труды: Духовный рыиарь. Некоторые черты о внутренней церкви, Москва 1997, s. 62.

${ }^{6}$ Siemion I. Hamalija (1743-1822) — pisarz, filozof-idealista, zajmował ważne miejsce w środowisku masonów moskiewskich w latach osiemdziesiątych XVIII wieku. Zob. М. В. Довнар-Запольский, Семен Иванович Гамалея, [w:] Масонство в его прошлом и настоямем, t. 2, s. 27-38; А. Незеленов, Литературные е направления..., s. 174-181. 
Всяк из нас знает, что мы рождаемся в сей мир не по нашей воле, должны жить не по нашей воле; человек не может у себя отнять ничего из своих душевных дарований, потому что не от себя их имеет. Как дерзает он отнимать у себя свою временную жизнь, которая есть начало вечной его жизни, и которую также не от себя имеет? [...] Итак, любезные братья, мы, яко ученики добродетели, постараемся умертвить все свойства недоброй нашей воли, дабы чрез то дать свободу возраста свойствам доброй воли. Возлюбим смерть недобрых наших свойств, недобрых прихотей, зная, что от сего зависит рост вечного нашего состояния ${ }^{7}$.

Podobna idea została wyeksponowana w obrzędowej pieśni lożowej Гимн (Hymn, b.r.w. ${ }^{8}$ ) pióra Fiodora Kluczariewa ${ }^{9}$. Refleksje ja lirycznego o istocie relacji pomiędzy Bogiem a człowiekiem dobitnie eksponują masońską tezę, iż człowiek uwolniony od marności świata, pokonawszy śmierć, może odrodzić się w doskonalszej formie i dostąpić poznania niepoznawalnego:
Мирской гнушаясь суетою,
Облекши мысли чистотою,
Стремитесь, верные сердца,
Познать всевышнего творца. [...]
Из жизни в смерть, чрез смерть в живот
Родиться дух и ветвь зелена [...]
О дух! Зри тройственный завет:
Престол, ковчег, святых святая!
Расторгнув мудрости покров,
Зри связь и сущность всех миров [...]
Подъявши крест, стал духом новым [...]
Вспарил превыше облаков,
Услышал хоры, песни, радость,
О мой Господь! О свет Светов,
Я с ним, я в нём, о жизнь! О сладость!
В нём сердце, мысли, ум и взор,
Греми со мной небесный хор ${ }^{10}$.

${ }^{7}$ Суt. zа: Г. В. Вернадский, Русское масонство в ияарствование Екатерины II, Санкт-Петербург 1999, s. 198-199.

${ }^{8}$ Lożowy hymn obrzędowy autorstwa F. Kluczariewa odnaleziony przez W. Sacharowa, opublikowany w pracy В. И. Сахаров, Иероглифы вольных каменщиков. Масонство и русская литература XVIII-начала ХIX века, Москва 2000, s. 170.

${ }^{9}$ Fiodor P. Kluczariew (1755-1822) — członek towarzystw Собрание университетских питомцев (1766) M. Nowikowa Дружеское учёное общество (1781) і Вольное российское собрание (1782). Uczestniczył w pracach loży Озириса, był mistrzem stołu, a następnie przewodniczył loży Святой Моисей (1781 lub 1782), w 1782 roku został wybrany jednym z pięciu członków dyrektorii prowincji masońskiej Строгое наблюдение. W maju 1792 roku podał się do dymisji, co uchroniło go przed prześladowaniami ze strony Katarzyny II. W 1809 roku ponownie został członkiem loży K мертвой голове. Zob. Словарь русских писателей XVIII века, t. 2, Санкт-Петербург 1999, s. 67-70.

10 Ф. Ключарев, Гимн, [w:] В. И. Сахаров, Иероглифы вольных каменщиков..., s. 170. 
Rozważania filozoficzne o istocie śmierci stanowią ważki komponent ideowy w dorobku artystycznym Michaiła Chieraskowa ${ }^{11}$ - jednego z najwybitniejszych rosyjskich poetów masońskich XVIII wieku. Autor Rossijady (Россиада, 1779), aktywny różokrzyżowiec, w swoich wierszach kieruje uwagę odbiorcy ku ideałom wolnomularskim. W środowisku braci masonów poezja, jak wiadomo, miała szczególny status, była formą poznania przyjemnego. Poeta, natchniony wybraniec Boga, zdolny był poprzez wieszcze poetyckie słowo wnosić w dusze wtajemniczonych i profanów harmonię i piękno, był nauczycielem, prorokiem, predestynowanym objaśniać ukryte sensy, wpływać na kształtowanie duchowe braci.

Zarówno w cyklach lirycznych Chieraskowa Подчерпнутые мысли из Экклезиаста (Myśli zaczerpnięte z Eklezjasty, 1764), Три начальные главы из премудростей Соломоновых (Trzy początkowe rozdziały z madrości Saloтопа, 1764), Философические оды (Ody filozoficzne, 1769), jak i jego poematach i prozie wielokrotnie powracają motywy eschatologiczne.

Подчерпнутые мысли из Экклезиаста to swoisty traktat o sensie życia, miejscu człowieka w boskim dziele. Ja liryczne dokonuje w nim wewnętrznego rozrachunku z samym sobą. Rozważania o beztroskiej, radosnej młodości ujawniają głębię rozterki duchowej poety, boleśnie uświadamianą złudność dążenia do osiągnięcia spełnienia. Pełne iluzji młodzieńcze marzenia o bogactwie, sławie, stanowiskach, pięknie czy wiedzy — z goryczą konstatuje podmiot mówiący pozostają tylko pragnieniami, wiodą ku zwątpieniu, niczego nie są w stanie zmienić. Odwieczny porządek świata był i pozostanie niezależny od woli człowieka, nieprzerwanie, bez względu na status, podążającego ku śmierci. Człowieczy los jest „marnością nad marnościami”, a szczęście sprowadza się do posiadania tego, co jest niezbędne. Śmierć jest naturalnym zjawiskiem, które zrównuje wszystkich — w jednakowym stopniu dotyczy każdej żywej istoty, unicestwia wyjątkowość jednostki, niweczy każdy zamysł i plan, zaciera ślady istnienia:

В единую земли утробу отнесется

И добрый человек, разбойник и злодей.

Ты славу думаешь приобрести себе:

Умрешь - погаснет все, чем разум ни светлеет;

Никто уж о тебе на свете не жалеет,

Загладит люта смерть и память о тебе.

Исполнен век напасти,

Но жить мы хотим;

Стяжаньем сильной власти

11 Michaił M. Chieraskow (1733-1807) - związał się z ruchem wolnomularskim około 1773 roku. W latach 1773-1774 był członkiem petersburskiej loży Herpokrates, w 1776 roku wielkim mówcą w loży Ozyrys. Brał czynny udział w zjednoczeniu lóż systemu I. P. Jełagina i I. Reichela. Uczestniczył w organizowaniu loży Harmonia (1780-1783) i kapituły Latona (1780). Był założycielem, a następnie wielkim oratorem w Loży Prowincjonalnej systemu różokrzyżowców (Zakonu Złotego i Różanego Krzyża) w Moskwie. Zob. Словарь русских писателей ХVIII века, t. 3, Санкт-Петербург 2010, s. 345-361. 
Себя до смерти льстим:

Но кто Престолом обладает,

Кто служит, всех земля сравняет ${ }^{12}$.

Człowiek, uświadamiając sobie nieustannie nieuchronność śmierci, dotkliwie odczuwa jej obecność. Proces umierania ciała, fizjologia śmierci wywołują jego lęk i pokorę przed tym, co po tamtej stronie:

Кипящая кровь во мне простынет и замерзнет,

Померкнут очи, мысль притупится моя,

Сосуды в ключевых потоках сокрушатся,

И вкус мой услажден не будет уж ничем.

Трепещусь, слаб, согбен я стану приближаться

Ко прогу вечности ${ }^{13}$.

Dla ja lirycznego śmierć jest więc katalizatorem jego postawy wobec życia. Świadomość, że jest jedynie chwilowym gościem na ziemi, a przed ponownym włączeniem w boski porządek świata stanie przed obliczem Stwórcy, obliguje go do przestrzegania zasad ustalonych Jego odwiecznym planem. Tylko istnienie wedle nich, przekonanie o nieustającej bożej opiece, pozwala mu zachować równowagę duchową:

Вкушай приятности сего текуща века,

Но Бога не забудь! храни Его закон,

И то в уме тверди: что создал человека,

Дабы на суд к Нему предстал по смерти он ${ }^{14}$.

W przejmująco emocjonalnych rozważaniach podmiotu lirycznego o istocie Boga ijego stosunku do człowieka w cyklu Триначальныеглавы из Премудростей Соломоновых роwraca idea przypadkowości człowieczej egzystencji. Chwilowemu gościowi na ziemskim padole, uwikłanemu w marności świata i własną niedoskonałość, nadzieję daje świadomość, że śmierć jest jednocześnie zapowiedzią obietnicy istnienia w doskonalszej formie:

Не создал смерти Бог на свете,

Ниже погибели живым;

Спасение положил в завете

И скуки не назначил им ${ }^{15}$.

Jednakowa dla wszystkich śmierć - konstatuje poeta - to jednocześnie początek nowego życia. Pesymizm wynikający z uzmysłowienia ulotności życia

12 М. М. Херасков, Подчерпнутые мысли из Экклезиаста, [w:] Творенія М. М. Хераскова, вновь исправленныя и дополненныя, t. 7. Разньля сочиненія, орrac. А. И. Любжин (wеdług Творенія М. М. Хераскова, вновь исправленныя и дополненныя, t. 7, Москва 1796-1803), Мюнхен-Москва 2009, s. 5.

13 Ibidem, s. 11.

14 Ibidem, s. 13.

15 М. Херасков, Три начальные главы из премудростей Соломоновых, [w:] Творенія М. М. Хераскова..., s. 11. 
łagodzi więc obietnica odrodzenia. Jego warunkiem jest miłość do Boga i podporządkowanie się Jego tajemnemu planowi. W porównaniu z tekstem biblijnym nastroje pesymizmu w wierszu Chieraskowa zostają złagodzone i wyciszone. Człowiek nie jest skazany na samotność, a Bóg jest sprawiedliwy, nieustający w opiece, wiecznie czuwa nad każdym człowieczym uczynkiem ${ }^{16}$ :

Бог зрит дела твои, а Сам везде с тобою [...]

Пылинка человек, и точка в мире сем,

Но от пресветлого, небесного чертога,

Взирает на него, печется Бог о нем.

Не бойся никого, о смертный! - бойся Бога ${ }^{17}$.

W odzie V O суетных желаниях z cyklu Новые оды (1762) ja liryczne dwukrotnie staje w obliczu śmierci. Zafascynowany potęgą szalejącego morskiego żywiołu poeta kreśli monumentalną wizję katastrofy morskiej. Wzburzone fale, wyjący wicher, ciemność przecinana krwawymi błyskawicami, okręt wyrzucany ku niebiosom i pogrążający się w odmętach są tłem ludzkiej tragedii. Poeta widzi, słyszy i boleśnie doświadcza rozpaczy wędrowców:

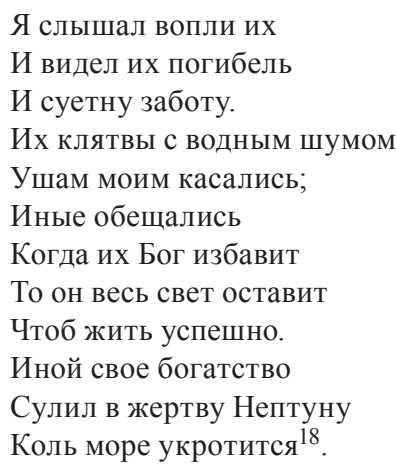

W poszukiwaniu uspokojenia ja liryczne zapuszcza się następnie w leśne ostępy. Pogoń za złotorogim, srebrzystoskórym jeleniem nieoczekiwanie finalizuje walka z lwem z ociekającą krwią paszczą. Wyrwawszy się z opresji (celnym strzałem w porywie rozpaczy uśmiercił zwierzę), nieoczekiwanie odkrywa sens obu zdarzeń. Zarówno tragedia marynarzy, jak i leśna przygoda uświadamiają mu, że przyczyną tragizmu egzystencji człowieka nie są żywioły i dzikie zwierzęta, lecz jego osobiste namiętności i pragnienia, nakazujące pogoń za marnościami świata:

Не море в том виною,

Не ветры и не звери,

Когда мы погибаем [...]

${ }^{16}$ A. Orłowska, Motywy biblijne w liryce i poematach Michała Chieraskowa, [w:] Biblia w literaturach $i$ w folklorze narodów wschodniostowiańskich, red. R. Łużny, D. Piwowarska, Kraków 1998, s. 143-157.

17 М. Херасков, Подчерпнутые мысли из Экклезиаста..., s. 9.

18 М. Херасков, О суетных желаниях, [w:] Творенія М. М. Хераскова..., s. 132. 
Виною в том желанья,

Которы нас приводят

За тленностью гониться.

Кто льстится суетою

Гоняется за тою,

Тот на свирепом море,

Или на твердом месте

Равно погибнуть может ${ }^{19}$.

Natomiast w wierszu Сельская муза poeta apeluje do pogrążonych w doczesnych rozkoszach, dalekich od natury braci masonów o chwilę refleksji nad życiem, nad samym sobą, nad sensem swego istnienia. Jeżeli nieobca ci jest natura, jeśli nie odczuwasz lęku przed kontaktem z przyrodą, przyjdź do mnie pod cień drzew zaprasza poeta - aby pojąć piękno bożego dzieła, podzielić ukojenie zrodzone z kontaktu z naturą. Jednakowo szczodre dla wszystkich zielone pola, ukwiecone łąki, żyzne łany zbóż są świadectwem nieskończoności i piękna bożego dzieła. Są jednocześnie przemądrą księgą, która pozwala człowiekowi zmierzyć się z wielkością i sensem bożego planu. Nieustająca zmienność natury, która niczym mityczny Proteusz ciągle jawi się w innym kształcie, budzi jego zachwyt i lęk, jednocześnie dając nadzieję:

Трава, как человек, рождается на свете

Бывает в юности, бывает в лучшем цвете;

Ко старости она равно как мы придет

Лишится сил своих, увянет и умрет.

Всему творению закон сей дан Судьбою

О бедный человек, все сходствует с тобою ${ }^{20}$.

Pytanie o kres istnienia, pogrążenie się $\mathrm{w}$ niebycie, jest w tym kontekście nieuzasadnione. Przyroda nieustannie odradza się bowiem do życia. Jej cykliczność pozwala mieć nadzieję na katharsis po tamtej stronie. Tym bardziej że człowiek jako jedyny dostał od Boga duszę:

С ползущей тварию одну судьбу имеем.

Равно рождаемся, равно по смерти тлеем [...]

Не вид от червяка нас тленный отличает

Но то, что душу в нас бессмертие венчает ${ }^{21}$.

Ponowne włączenie w porządek boskiego, harmonijnego istnienia wymaga jednakże od człowieka wysiłku, świadomego zmagania się ze swoimi ułomnościami, wolną wolą i iluzoryczną wartością otaczającego go realnego świata:

Но чтоб венец такой Натура нам дала

Едины добрые потребны нам дела [...]

Коль вечной жизни ты желаешь человек

То благочестием укрась текущий век [...]

\footnotetext{
19 Ibidem, s. 134.

${ }^{20}$ М. Херасков, Сельская муза, [w:] Творенія М. М. Хераскова..., s. 239.

${ }^{21}$ Ibidem, s. 242.
} 
Будь кроток, милосерд, смирен, благочестив, Разрушится весь мир, но дух твой будет жив.

Увидишь Бога ты душевными очами

И будешь озарен бессмертными лучами ${ }^{22}$.

Tragiczny finał człowieczego życia jest więc dziełem samego człowieka. Pogrążony w marnościach świata niweczy swoją perspektywę wpisania się w idealny boski plan, skazuje się na udrękę strachu przed kresem istnienia:

Когда же сам к себе ты стал бесчеловечен,

Жизнь кончишь в суетах и будет сон твой вечен ${ }^{23}$.

Wszechobecna obsesyjna myśl o śmierci i fascynacja śmiercią pozwalają braciom zmierzyć się z istotą antropologicznej eschatologii myśli wolnomularskiej. Życie doczesne człowieka to marność, udręka i ból. Refleksja nad sobą, odkrywanie kolejnych tajemnic natury i samego siebie gwarantuje jednakże przezwyciężenie pesymizmu i rozpaczy oraz dekomponuje katastroficzną wizję istnienia.

\section{Bibliografia}

Вернадский Г. В., Русское масонство в иарствование Екатерин II, Санкт-Петербург 1999. Довнар-Запольский М. В., Семен Иванович Гамалея, [w:] Масонство в его прошлом и настоящем, red. С. П. Мельгунов, Н. П. Сидоров, t. 2, Москва 1915.

Ключарев Ф. П., Клятва, [w:] В. И. Сахаров, Иероглифы вольных каменшиков. Масонство и русская литература ХVIII-начала ХІХ века, Москва 2000.

Лопухин И. В., Нравоучительный катехизис истинных франкмасонов для употребления ищущих премудрости, [w:] И. В. Лопухин, Масонские труды: Духовный рыцарь. Некоторые черты о внутренней церкви, Москва 1997.

Незеленов А., Литературные е направления в Екатеринскую эпоху, Санкт-Петербург 1898.

Пиксанов Н. К., Ив. В. Лопухин, [w:] Масонство в его прошлом и настоящем, red. С. П. Мельгунов, Н. П. Сидоров, t. 1, Москва 1915.

Русская философия 2-ой половины ХVІІІ века. Хрестоматия, red. Б. В. Емельянов, Свердловск 1990.

Сахаров В. И., Иероглифы вольных каменщиков. Масонство и русская литература XVIIIначала ХІХ века, Москва 2000.

Словарь русских писателей ХVIII века, t. 2, Санкт-Петербург 1999.

Словарь русских писателей XVIII века, t. 3, Санкт-Петербург 2010.

Соколовская Т. О., Обрядность вольных каменщиков, [w:] Масонство в его прошлом и настоящем, red. С. П. Мельгунов, Н. П. Сидоров, t. 2, Москва 1915.

Творенія М. М. Хераскова, вновь исправленныя и дополненныя, t. 7. Разныя сочиненія, орrac. А. И. Любжин (według: Творенія М. М. Хераскова, вновь исправленныя и дополненныя, t. 7, Москва 1796-1803), Мюнхен-Москва 2009.

Cegielski T., Sekrety masonów, Warszawa 1992.

Orłowska A., Motywy biblijne w liryce i poematach Michała Chieraskowa, [w:] Biblia w literaturach $i$ w folklorze narodów wschodniosłowiańskich, red. R. Łużny, D. Piwowarska, Kraków 1998.

22 Ibidem, s. 242-243.

23 Ibidem, s. 245.

Slavica Wratislaviensia 167, 2018

(C) for this edition by CNS 


\section{Death is not the end of existence... Facets of death in masonic poetry by Mikhail Kheraskov}

\section{Summary}

The obsessive fascination with death is ever-present in anthropological Masonic eschatology. In the poetry of Russian 18th century Masonic artist Mikhail Kheraskov, this fascination is expressed in a complex system of metaphorical images. The poetic vision enabled the initiated to confront the pains of existence. The mundane life means vanity, anguish and pain. However, self-reflection and discovery of further secrets of nature enables Masonic brothers to overcome pessimism and despair, undermining the catastrophic perspective of human fate.

Keywords: Russian Masons, lodge ceremonies, eschatology, Masonic poetry, Mikhail Kheraskov

\section{Смерть - не предел бытия... Облики смерти в масонской поэзии Михаила Хераскова}

\section{Резюме}

Увлечение вольных каменщиков смертью, навязчиво проявляющееся в антропологической орденской эсхатологии, воспроизводится в поэзии русского поэта-масона XVIII века Михаила Хераскова посредством сложной системы метафорических образов. Поэтическое слово позволяет посвященным осмыслять боль существования. Земная жизнь для масона - суета сует, душевные терзания и мучения. Раскрытие тайн натуры обещает преодоление пессимизма, уничтожает катастрофическую перспективу человеческого бытия.

Ключевые слова: русское масонство, орденские обряды, эсхатология, масонская поэзия, М. Херасков 